This article has been accepted for publication in the Journal of Medical Ethics 2021, the Version of Record can be accessed online at doi.org/10.1136/medethics-2021107615.

Joona Räsänen

Department of Philosophy, Classics, History of Art and Ideas, University of Oslo, Oslo, Norway

\title{
Abortion and the veil of ignorance: a response to Minehan
}

\begin{abstract}
In a recent JME paper, Matthew John Minehan applies John Rawls' veil of ignorance against Judith Thomson's famous violinist argument for the permissibility of abortion. Minehan asks readers to 'imagine that one morning you are back to back in bed with another person. One of you is conscious and the other unconscious. You do not know which one you are.' Since from this position of ignorance, you have an equal chance of being the unconscious violinist and the conscious person attached to him, it would be rational to oppose a right for detachment. Likewise, behind the veil of ignorance, it is rational to oppose abortions since you could be the fetus, Minehan claims. This paper provides a plausible reply to this argument.
\end{abstract}

It has been 50 years since Judith Jarvis Thomson's famous argument for the permissibility of medically induced abortion. In her paper, ${ }^{1}$ Thomson argued that even if the fetus is a person and has a right to life, the fetus has no right to use another person's body to sustain its own life; therefore, abortion is morally permissible and should be legally permitted.

Thomson's argument was based on the intuitions behind the case where you wake up in the hospital attached to a famous violinist whose kidneys have failed to function and who would die without your help. Although the violinist would die if you detach yourself from him, you are morally permissible to do so since he has no right to use your body to sustain his own life. By parity of reasoning, Thomson concluded that a fetus has no right to use a woman's body to sustain its own life so abortion must be morally permissible as well.

Thomson has her critics $^{2-3}$ and defenders ${ }^{4-5}$ and the discussion continues with further criticism $^{6}$ and new thought experiments in different context. ${ }^{7}$ In a recent JME paper, ${ }^{8}$ Matthew John Minehan argues that from the position of ignorance it is rational to oppose abortions and demand that a woman remains attached to the fetus. To make his case, Minehan cleverly asks his readers to imagine that one morning you are 
back to back in bed with another person. One of you is conscious and the other unconscious. You do not know which one you are.

Minehan claims that by framing the scenario this way, we create a position of ignorance. He then reasons that behind of this Rawlsian type of veil of ignorance ${ }^{9}$, since I would have an equal chance of being the violinist and the kidney surrogate and 9 months of inconvenience is greatly preferable to death it is rational to adopt a general rule that would prohibit disconnecting the violinist. This would mean that it is rational to prohibit abortion.

While Minehan provides an interesting argument, I think it is not successful. ${ }^{i}$ To see the problem of it, consider the survival lottery proposed by John Harris.

Survival Lottery. Suppose organ donation saves more individuals than it would kill. All individuals in the society are assigned a number and drawn out of the lottery when a donation is needed. They are expected to give up their lives to allow two or more people to live. ${ }^{10}$

Behind the veil of ignorance, it would be rational to comply with the survival lottery. After all, it is more likely that you will be the one who needs the organ rather than who has to donate one. But few would accept such a deal.

One lesson to be learned from this case is that even if by a utilitarian calculation something seems rational, people reasonable object practices that demand other people to be used in very constitutive ways. It applies for abortion. Even if by a utilitarian calculation (or contractarian reasoning) it seems rational to demand women to undergo unwanted pregnancy, people object to it because doing so would demand women to use their bodies in a very constitutive way.

But perhaps I am not fair here. In Survival Lottery, a person is being killed to save two or more people. But in abortion, a person is only asked to remain pregnant for nine months to save one life. Because of this, my reply does not work, one might claim.

However, we can adapt the case of survival lottery so that people are not being killed and consult our intuitions. Consider the following case.

Organ Lottery. Whenever a person is suffering from kidney failure and is destined to die, society draws out a lottery. A suitable person is looked up and for the nine months, his or her body will be used to save the kidney patient.

After that, the donor is free to go.

Rationally, we should adopt such a policy. Since you cannot know whether your kidneys will fail or whether you will be asked to hook up with the kidney patient for nine months it is rational to accept the organ lottery. But I doubt people would agree to such a practice. After all, we do not currently force people to donate kidneys even though most kidney donors can return to normal daily activities after two to four

\footnotetext{
i In his paper, Minehan offers another argument against Thomson: a self-aborting fetus. I leave it to other time to criticise his self-aborting fetus.
} 
weeks. People simply do not accept such cold utilitarian calculation when what is required is that their bodies will be used to benefit others.

Organ Lottery is a thought experiment created to show Minehan's argument to be unsound. But there are real-life cases similar to it that show the problem in Minehan's argument as well.

Consider stem cell transplant for leukaemia patients. For instance, every year, thousands of people in the U.S. are diagnosed with life-threatening diseases, such as leukaemia or lymphoma, for which a stem cell transplant is the only treatment. Donated blood stem cells are needed for these transplants. If there is no suitable donor, the patient will die. While the full recovery from the donation takes only a couple of weeks, no one is morally obligated to donate her stem cells and the state has no right to force people to donate stem cells to save the patient.

Unless we are willing to revise the current practices and force people to become stem cell donors, we can reasonably allow women to have abortions as well.

\footnotetext{
1 Thomson J. A defense of abortion. Philos Public Aff 1971;1:47-66.

2 Kaczor C. The Ethics of Abortion: Women's Rights, Human Life, and the Question of Justice. Routledge, 2015. $2^{\text {nd }}$ ed.

${ }^{3}$ Bernstein C'Zar, Manata P. Moral responsibility and the Wrongness of abortion. J Med Philos 2019;44:243-62

${ }^{4}$ Manninen, B. Rethinking Roe v. Wade: Defending the Abortion Right in the Face of Contemporary Opposition. Am J Bioeth 2010:10:33-46.

${ }^{5}$ Boonin D. Beyond Roe: Why Abortion Should be Legal-Even if the Fetus is a Person. Oxford University Press, 2019.

${ }^{6}$ Hendricks, P. My body, not my choice: against legalised abortion. J Med Ethics Epub ahead of print: [Published Online First: 18 May 2021] doi:10.1136/medethics2020-107194.

${ }^{7}$ Räsänen, J. Twin pregnancy, fetal reduction and the 'all or nothing problem'. J Med Ethics Epub ahead of print: [Published Online First: 21 Dec 2020]. doi:10.1136/medethics-2020-106938.

8 Minehan M. Moral status of the fetus and the permissibility of abortion: a contractarian response to Thomson's violinist thought experiment. J Med Ethics Epub ahead of print: [Published Online First: 07 May 2021]. doi:10.1136/medethics-2020106810.

${ }^{9}$ Rawls J. A theory of justice. Cambridge, MA: Belknap Press, 1971.

10 Harris J. Survival Lottery. Philosophy 1975;50:81-87.
} 